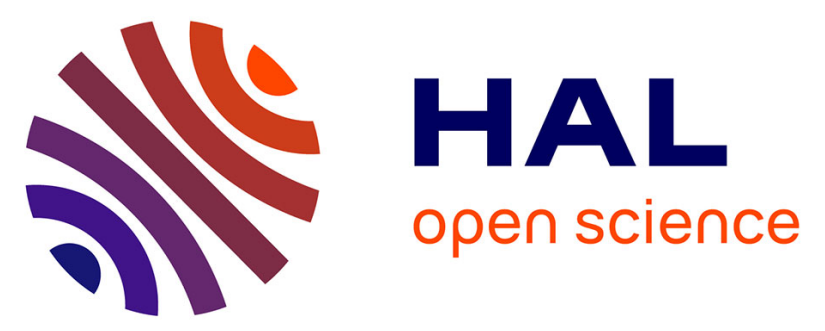

\title{
Je t'aime, moi non plus: Bilateral opinions and international trade
}

Anne-Célia Disdier, Thierry Mayer

\section{To cite this version:}

Anne-Célia Disdier, Thierry Mayer. Je t'aime, moi non plus: Bilateral opinions and international trade. European Journal of Political Economy, 2007, 23, pp.1140-1159. 10.1016/j.ejpoleco.2006.09.021 . hal-01021880

\section{HAL Id: hal-01021880 \\ https://hal-sciencespo.archives-ouvertes.fr/hal-01021880}

Submitted on 9 Jul 2014

HAL is a multi-disciplinary open access archive for the deposit and dissemination of scientific research documents, whether they are published or not. The documents may come from teaching and research institutions in France or abroad, or from public or private research centers.
L'archive ouverte pluridisciplinaire HAL, est destinée au dépôt et à la diffusion de documents scientifiques de niveau recherche, publiés ou non, émanant des établissements d'enseignement et de recherche français ou étrangers, des laboratoires publics ou privés. 


\title{
Je t'aime, moi non plus: Bilateral opinions and international trade
}

\author{
Anne-Célia Disdier ${ }^{\mathrm{a}, *}$, Thierry Mayer ${ }^{\mathrm{b}, \mathrm{c}, \mathrm{d}, \mathrm{e}}$ \\ a INRA, UMR INRA-AgroParisTech Economie Publique, 16 rue Claude Bernard, 75231 Paris Cedex 05, France \\ ${ }^{\mathrm{b}}$ Université Paris 1 Panthéon-Sorbonne, 106-112 Bld. de l'Hôpital, 75647 Paris Cedex 13, France \\ ${ }^{\mathrm{c}}$ Paris School of Economics, Paris, France \\ d CEPII, Paris, France \\ e CEPR, London, U.K.
}

Received 15 February 2005; received in revised form 5 December 2005; accepted 15 September 2006

\begin{abstract}
This paper studies the relationship between bilateral trade patterns and opinions. It uses the Eurobarometer public opinion surveys published by the European Commission, which provide data on the share of the population in each EU15 member country in favour of each CEEC joining the EU. Our results first suggest that bilateral opinions have a statistically robust and relatively large effect on imports, even when standard and new covariates capturing proximity between countries are controlled for. We interpret this effect as reflecting a positive impact of "bilateral affinity" on trade patterns. We also show that it is possible to go some way towards explaining the variance in bilateral opinions among our sample. Last we provide some preliminary attempt to determine causality between bilateral opinions and imports.

(C) 2006 Elsevier B.V. All rights reserved.
\end{abstract}

JEL classification: $\mathrm{F} 10$

Keywords: Gravity; Bilateral opinions; Enlargement

\section{Introduction}

Proximity helps exchanges. This has been an enduring result in the literature since the gravitational law has been proposed by economists as a description of bilateral commodity flows. ${ }^{1}$

\footnotetext{
* Corresponding author. Tel.: +3314408 72 72; fax: +33144081663.

E-mail address: disdier@inapg.fr (A.-C. Disdier).

1 Tinbergen, 1962, is often cited as the original study of this kind, but Isard and Peck, 1954, is an earlier study using gravity determinants of trade flows. Hundreds of papers have used the gravity model empirically since then.
} 
More debate emerges when it comes to what is a good definition of proximity. Physical distance should clearly enter this definition and always does, usually motivated as a proxy for transportation costs. This primary (inverse) measure of proximity still matters a great deal in trade patterns: In a meta-analysis on the impact of distance on bilateral trade, Disdier and Head (in press) report an average elasticity estimate of -0.91 , covering 1467 estimates in 103 studies. They also show that estimates are in fact rising over time since the 1950s, a result arguing against naive expectations about the current level of globalization.

More generally, the impact of proximity on trade can be divided into two components: The reduction of transaction costs (freight, but also communication and information costs) and bilateral affinity between the two countries (which notably influences preferences of consumers). This affinity is itself generated by a complex mixture of exogenous "historical accidents" (good or bad) that arose between the two countries, and more endogenous economic characteristics of the two countries.

Physical distance is clearly an imperfect and incomplete measure of this overall definition of proximity. First, some elements of transaction costs are not directly related to distance (variations in bilateral protectionist measures have no a priori reason to follow distance in a systematic way for instance). Second, bilateral distance has all chances to be a poor measure of bilateral affinity. Consider the example of cultural traits. We have all reasons to believe that countries sharing similar cultural features have i) more proximate tastes, ii) lower communication and information costs and iii) more trust that individuals in the other country will not adopt an opportunistic behaviour in contractual relationships as Guiso et al. (2004) emphasize. All of those will contribute to make trade larger. Cultural proximity is likely to be correlated with physical distance, for the simple reason that a lot of cultural features travel embodied in people, and that migrations are strongly impeded by distance. It is however imperfectly captured by distance. Empirical support for this view can be found in the literature about network effects in international trade. This body of work recently surveyed in Rauch (2001) and Wagner et al. (2002), has repeatedly found that bilateral migration is a robust trade-promoting force, even after controlling for bilateral distance. The very robust and large positive impact on trade flows of common language and colonial links that are routinely introduced in gravity equations, is a further sign that cultural aspects of proximity are important in international commerce, in addition to distance. We use here a new type of information, the bilateral opinions expressed by surveyed populations in European Union 15 (EU15) member countries about the enlargement to Eastern European countries, to capture more precisely the impact of proximity on trade patterns.

Bilateral opinions are of course themselves not random. They are affected by a host of different elements that we will investigate here, some of them stemming from non-economic characteristics of the two countries, some of them deeply affected by the endogenous economic environment, particularly in our case where the question asked relates to the desirability of enlargement and therefore of international integration with a specific trade partner. The intensity of trade flows is likely to be one of those economic determinants of bilateral opinions. We can refer to this influence as the "non-traditional" effects of trade. The relationship between trade patterns and bilateral affinity has rarely been studied in the literature (Guiso et al., 2004 being a recent exception). Several channels can be envisioned to the impact of trade on opinions, one stipulating that large trade volumes help diffuse information and cultural traits, reduce bilateral ignorances and fears, which might translate in better bilateral opinions everything else equal. A reverse argument can however also be used. Opinions can be guided by fears of strengthened competition with the entry of candidate countries. A large bilateral trade volume can thus yield an overall lower level of positive opinions under this view, reflecting demand for protection. This phenomenon is likely to be all the more important that the two countries are specialized in the 
same industry, in which case expectations of large adjustment costs following the enlargement are high. ${ }^{2}$ This is emphasized in a recent and related work by Mayda and Rodrik (2005), who find using individual data that the demands for protectionism are significantly higher in industries most exposed to foreign competition. Regarding our sample of countries, note that the number of anti-dumping investigations conducted by EU against CEECs has significantly increased at the end of the 90s. The number of anti-dumping initiations registered only started to decrease substantially in $2002 .^{3}$

While our opinion data are not available at the individual level, as in Mayda and Rodrik (2005) they have the advantage of having a bilateral dimension (and also a - short - temporal one). We use these data to investigate the relationship between trade integration and bilateral opinions in both directions. We therefore try to address the following questions: First, is there an influence of opinions on bilateral trade, even after controlling for often used proximity variables? Second, what are the determinants of those bilateral opinions? We also investigate causality using the drastic trade policy changes over the period as an instrument for trade volumes.

The remainder of the paper is structured as follows. The related empirical literature is presented in Section 2. The data are described in Section 3. In Section 4 we present our specification and report the results from the contemporaneous correlation. The method used for causality analysis and results of this analysis are detailed in Section 5. Section 6 concludes.

\section{Related empirical literature}

\subsection{Bilateral affinity as a determinant of bilateral trade}

Several forms of trade partners' bilateral affinity have been studied in the literature, with different mechanisms of influence. Two measures have quite a long history in the gravity equation literature: linguistic similarity and past colonial links.

International trade tends to be promoted by the linguistic proximity of countries. This finding most often uses the simplest possible measure, a dummy variable set to one when the two countries speak the same language. A typical estimate for this variable is 0.5 (Frankel, 1997 for instance), which means that sharing a language increases trade flows by around $65 \%$. Boisso and Ferrantino (1997) and Melitz (2003) have investigated continuous measures of linguistic similarity and showed that bilateral trade tends to decrease with the linguistic distance. Junius and Nitsch (2001) also investigate the impact of language on trade through the inclusion of a bilateral ethno-linguistic fragmentation variable in a gravity study. They find that the product of ethnolinguistic fragmentation of partner countries has a positive impact on trade and interpret this as evidence of the importance of cultural proximity in reducing search costs.

Colonial links have also been shown to be trade-enhancing. Several channels can again be envisioned. First, colonizing powers have usually established trade networks in the colonized countries and those networks can persist even after the colonial episode. ${ }^{4}$ Second, being colonized often involves adoption of the institutional framework of the colonizer (with some

\footnotetext{
2 The adjustment costs will be particularly strong in a Heckscher-Ohlin framework where trade liberalization may eliminate an entire sector. In an imperfect competition-love of variety model, the costs will be lower. We thank one of the two referees for this remark.

33 new investigations were initiated in 1996, 5 in 1997, 6 in 1998, 8 in 1999, 6 in 2000, 7 in 2001, and 1 in 2002. Since 2003, no new investigation has been initiated. Source: European Commission, DG Competition website.

4 The importance of formal and informal networks in international trade has been recently emphasized (see Rauch, 2001 , for an overview of this literature).
} 
variance depending on the colonizer and the colonized country as emphasized by Acemoglu et al., 2001). Such institutions involve legal rules and administrative systems that can affect the ease of international trade through an improvement in the security of transactions or a reduction in communication costs due to similarity in the institutional framework. Note that this can explain why an ancient colony still trades more than expected ${ }^{5}$ with its ex-colonizer, but also why two countries having had the same colonizer have larger than expected bilateral trade flows. Rose (2000) has implemented this using dummies for historical colonial links and for the fact that the two countries have had the same colonizer. The impacts found are extremely large. In his benchmark results for 1990, the colonial relationship raises bilateral trade by a factor of exp $(1.75)=5.75$, everything else equal, while having had a common colonizer make countries' bilateral trade $\exp (0.59)-1=80 \%$ larger. It is interesting to note also that those coefficients were substantially larger for the year $1970 .^{6}$

Linked to this literature is the body of work studying the existence of business and social network effects in trade, through the estimation of the explanatory power of international migrations patterns on bilateral trade. Wagner et al. (2002) provide a comparison of this set of papers analysing the immigration-trade link. Immigrants promote exchanges between their origin and host countries in two major ways. The first one works through a diffusion-of-tastes channel, since immigrants keep at least part of their preference for goods produced in their origin country, and might also yield some locals to acquire tastes of immigrants on a certain number of goods. Immigrants also bring with them additional information about trade opportunities and demand characteristics in their origin country, which entails a reduction in transaction costs. The empirical results often find robust and large estimates for both the impact of immigration on imports and exports linkage, providing support for the information channel, at least as much as for the diffusion of preferences' one.

Last and most related to our work, is the very recent paper by Guiso et al. (2004) on bilateral trust and economic exchanges. They use the Eurobarometer survey, as we do here, but they rely on answers to a different question, the one about the level of bilateral trust between citizens of different countries. Their main argument is that bilateral trust is built in each country through a process in which cultural biases are important, and those later influence bilateral economic relationships. Indeed, lack of bilateral trust makes people reluctant in starting a contractual relationship, which in return forbids the level of knowledge of potential partners in the other country to increase, and hence trust can never reach a level where trade or investment is expected to be profitable. Introducing this variable in bilateral trade and FDI equations, they find a robust positive impact of trust on trade flows, less so on FDI.

\subsection{The determinants of opinions}

How are bilateral opinions determined? The existing literature has used as dependent variables individual level opinions on the protectionist sentiment (Mayda and Rodrik, 2005; O'Rourke and Sinnott, 2006) and on the will in candidate countries to enter the EU (Doyle and Fidrmuc, 2006).

\footnotetext{
${ }^{5}$ Expected in the sense of predicted by the gravity equation, i.e. given the economic sizes of both trade partners and the distance between them.

${ }^{6}$ Eichengreen and Irwin (1998) also illustrate this influence. Their research on bilateral trade between countries of the former British Empire and of the British Commonwealth, between the United States and the Philippines, and between the Netherlands and the Indonesia for the years 1949, 1954 and 1964 confirms that these colonial links have a significant influence on trade.
} 
They therefore only have information on "non-dyadic opinions" which they try to explain with "nondyadic opinions" determinants.

A large number of such determinants have been proposed in those papers. They refer to the economic characteristics of countries and individuals (using essentially information on endowments and industries) and to the non-economic perceptions by citizens. Our research is here closely related to the one by Mayda and Rodrik (2005) on the determinants of individual opinions in relation to international trade. Several results are of direct interest for our work. First, people with a high level of education and skill disagree strongly with trade restrictions only if their country is human capital abundant. Besides, the degree of trade openness of the sector in which an individual is employed seems to influence his opinion. People belonging to non-traded sectors are more in favour of international trade. Among the traded sectors, individuals in sectors with a comparative disadvantage are more protectionist. A positive relation exists also between the social status - either defined in terms of relative income or the subjective perception of it - and opinions in favour of international trade. Last, these individual opinions are significantly influenced by various non-economic elements: everything else equal, individuals strongly attached to their neighbourhood and to their country are more protectionists. On the other hand, those who have greater confidence in political and economic institutions appear more open to international trade. Doyle and Fidrmuc (2006) study the results of an opinion poll conducted in March/April 2002 in which citizens from 13 candidate countries in Eastern Europe are asked whether they would vote for or against EU membership in a referendum. They find that a high level of education, youth, a relatively high income, and living in an urban area increases the support for EU membership, while individuals who should benefit from the EU redistribution system surprisingly do not support membership. Contrary to Mayda and Rodrik (2005) or O'Rourke and Sinnott (2006), Doyle and Fidrmuc (2006) however do not really consider whether the trade theory predictions are backed up by opinions. Compared to this literature explaining opinions, we have here a bilateral dimension in the data. For example, we know the percentage of Italians supporting the enlargement to Bulgaria and the one in favour of the enlargement to Hungary. This additional dimension allows analysis of new determinants, as will be clear below.

Guiso et al. (2004) attempt to explain how bilateral trust is built between two nations. They also incorporate fixed effects for each of the two countries in the relationship to account for nation-specific characteristics that do not vary over time and make a country more likely to trust or to be trusted (its long term history of warfare for instance). Their main determinants of trust in terms of significance are the commonality of legal origin, genetic distance, which probably captures a common origin region of both populations, a common history, large population exchanges.... The impact of a variable capturing the level of information (number of times the name of the other country is cited in the newspapers) is negative when statistically significant, which they interpret as a negative bias spread by newspapers when they talk about a country. The data used by Guiso et al. (2004) have a bilateral dimension but their study does not include economic determinants of trust. Our contribution can therefore be seen as an intermediate between this type of analysis and the one about protectionist opinions seen above. We bridge the two types of work by studying bilateral opinions about economic integration.

\section{Data}

Our empirical implementation uses annual data for European countries (14 EU countries and 10 Applicant countries). We have data for seven years: 1992, 1994, and from 1997 to 2001. Separated statistical series for Belgium and Luxembourg have been unavailable until recently (notably on trade flows), we exclude Luxembourg from the sample of opinions, its weight in the 
trade flows of Belgium-Luxembourg is usually very low. Besides, Austria, Finland and Sweden are considered in the survey only since their membership and therefore only appear in our sample starting in 1997. The ten CEECs are Bulgaria, Czech Republic, Hungary, Poland, Romania, Slovakia, Slovenia, and the three Baltic States, namely Estonia, Latvia and Lithuania. For concision purposes, data sources and descriptive statistics are given in the Appendix. A correlation matrix is also available upon request.

Bilateral trade data - between each EU country and each CEEC - consist in aggregate flows. In order to uncover potential differences depending on the direction of the trade flow, the relationship between trade and opinions is studied separately for imports and exports. Our measure of opinions is extracted from the Eurobarometer public opinion surveys published by the European Commission. These biannual surveys have been conducted since 1973 in each Member State. They present an analysis of public opinion towards the European Union (European institutions, enlargement, support for European construction, etc.). An identical set of questions is asked to representative samples of the population aged fifteen years and over in each Member State. All interviews are face-to-face in people's home and in the appropriate national language. The regular sample consists of 1000 people per country with some exceptions. ${ }^{7}$ Our measure of opinions is based on the following question:

For each of the following countries, would you be in favour of or against it becoming part of the European Union?

Countries cited in the list are the 10 applicant CEECs, Cyprus, Malta, and (according to the year of the survey) Turkey, other Eastern European countries (e.g. Albania, Bosnia and Herzegovina, Croatia) and Western European countries (Iceland, Norway, Switzerland, and before their membership - Austria, Finland and Sweden). For reasons of sample homogeneity, our empirical implementation covers only the ten CEECs. All of them were indeed transition countries at the beginning of the 90s and have recently joined (or will join in the next months for Bulgaria and Romania) the European Union. Possible answers are "In favour", "Against", "Don't know". Results are expressed as a percentage of the total of the answers. The definition of our opinion variable is based on the percentage of positive answers. In the estimations, these values are drawn into the interval [0;100]. Questions appearing in the Eurobarometer surveys are however not asked at regular intervals. The availability of the chosen question for the evaluation of opinions limits our analysis to the years 1992, 1994 and from 1997 to 2001. As previously mentioned, the Eurobarometer surveys are conducted twice a year. However, our trade data are available only on an annual basis. We therefore retain for each year the mean of the answers from both biannual surveys.

Table 1 summarizes the opinions' data in each EU country. Statistics on the opinions in each EU country are calculated for three groups of CEECs. These groupings follow the geographical classification adopted by the CIA in its factbook. The first one (group A) includes countries from Central Europe, namely the Czech Republic, Hungary, Poland, Slovakia, and Slovenia; Baltic States (Estonia, Latvia, and Lithuania) constitute a group (group B) of their own; last, the two South-Eastern European countries of our sample - Bulgaria and Romania - form the third group (group C). For each group, the average opinion expressed in 2001 and variations of this opinion for the sub-periods 1992-1997 and 1997-2001 are reported (in percentage points).

\footnotetext{
${ }^{7}$ Current exceptions are for Luxembourg (600), the United Kingdom (1000 in Great Britain and 300 in Northern Ireland), and Germany (2000 people: 1000 in East Germany and 1000 in West Germany).
} 
Table 1

Opinions of EU citizens towards adhesion of CEECs (\%)

\begin{tabular}{|c|c|c|c|c|c|c|c|c|c|}
\hline \multirow[t]{2}{*}{ Country } & \multicolumn{3}{|l|}{ Group A } & \multicolumn{3}{|l|}{ Group B } & \multicolumn{3}{|l|}{ Group C } \\
\hline & Opinion in 2001 & $\Delta_{01 / 97}$ & $\Delta_{97 / 92}$ & Opinion in 2001 & $\Delta_{01 / 97}$ & $\Delta_{97 / 92}$ & Opinion in 2001 & $\Delta_{01 / 97}$ & $\Delta_{97 / 92}$ \\
\hline Austria & 44.8 & 19.3 & & 35.7 & 28.3 & & 24 & 33.3 & \\
\hline Belgium & 43.4 & 46.6 & -31.8 & 40.7 & 59.6 & -34.5 & 37.5 & 44.3 & -40.9 \\
\hline Denmark & 62.2 & 6.8 & 50.4 & 70.3 & -1.2 & 14.8 & 45.5 & 2.3 & 43.7 \\
\hline Finland & 48 & -2.7 & & 60 & 5.2 & & 34 & -9.7 & \\
\hline France & 28.8 & -11.8 & -21.8 & 20.3 & -13.5 & -31.5 & 26 & -16.1 & -25.9 \\
\hline Germany & 42.8 & 26.5 & -19.4 & 41.3 & 41 & -38 & 27.5 & 39.6 & -39.7 \\
\hline Great Britain & 38.6 & -1.3 & -16.9 & 33 & -5.3 & -9.1 & 35.5 & -5.3 & -11.7 \\
\hline Greece & 62.6 & 12 & 36.9 & 57 & 17.5 & 50.1 & 61.5 & 7 & 16.3 \\
\hline Ireland & 45.2 & 12.8 & 11.7 & 41 & 12.4 & 14.2 & 42 & 5.1 & -5.9 \\
\hline Italy & 49.2 & 9.6 & -9.7 & 39.3 & 10.3 & -8.5 & 46 & 9.5 & -12.2 \\
\hline The Netherlands & 48 & -16.6 & 10.2 & 47.7 & -10.9 & -1.3 & 38.5 & -19.8 & 9.2 \\
\hline Portugal & 47 & 24.2 & -10.4 & 42.3 & 26.4 & -4.2 & 47.5 & 26.7 & -25.8 \\
\hline Spain & 51.2 & 6.3 & -2.5 & 48 & 9.9 & 4 & 50.5 & 1.5 & -1.5 \\
\hline Sweden & 69.8 & 17.4 & & 76.3 & 13.4 & & 59.5 & 23.3 & \\
\hline EU average & 48.7 & & & 46.6 & & & 41.1 & & \\
\hline
\end{tabular}

Notes: Group A: Czech Republic, Hungary, Poland, Slovakia, and Slovenia; group B: Estonia, Latvia, and Lithuania; group C: Bulgaria and Romania. Opinions and their variations are in $\%$. These variations refer to the percentage change in the opinion poll percentage.

First, we note that the average support for enlargement varies depending on which country you ask them should join (49\% for group A, 47\% for group B and only $41 \%$ for group C). Support for enlargement varies also between Member States. Interestingly, people in Sweden, followed by people in Greece and Denmark, tend to be most supportive. On the opposite, France and the United Kingdom tend to have the least supportive opinions in 2001. This first pattern shows that controlling for structural differences in the level of support in each Western European country and also for the average level of support towards each CEEC will be crucial, and we will include country-specific fixed effects as a consequence.

Fig. 1 provides two graphical descriptions of the distribution of public opinion favourable to the enlargement in each EU country. These opinions are represented on the horizontal axis. Panel (a) shows the level of opinions expressed in 1992, 1994, 1997 and 2001. EU countries are
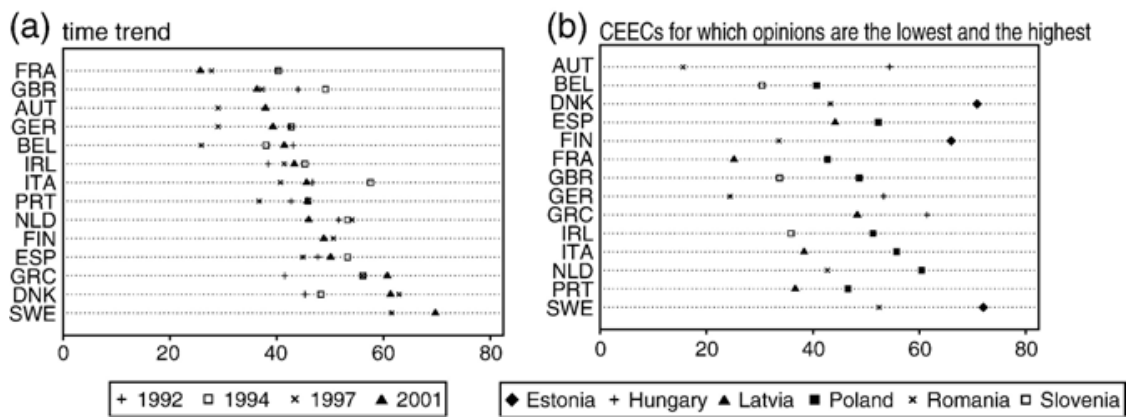

Fig. 1. Evolution of opinions expressed in each EU country in favour of enlargement. (a) Time trend, (b) CEECs for which opinions are the lowest and the highest. 
ranked using the level of their opinions in 2001. Two facts seem noteworthy: First, some countries are constantly more in favour of the enlargement than others. In particular, Denmark and Sweden, followed by Greece, are among the highest supporters of the enlargement, for almost all years. Second, opinions are not always improving over time. For all countries (except Belgium), the level in 1994 is very similar to the one in 1992 or higher. This is however followed by a strong reduction between 1994 and 1997. In 1997, opinions have deteriorated in most countries (except in Denmark, Netherlands and Greece). Opinions in 2001 are better than in 1997 for 9 countries of our sample and worse for the rest of them. Panel (b) shows for each EU country, the CEEC for which average bilateral opinions over the whole time period of our sample ( 7 years) are the smallest and the CEEC for which, these opinions are the highest. The influence of geographical proximity appears clearly here: For example, all the Nordic countries in our sample (Denmark, Finland and Sweden) have Estonia as their preferred joining member for the enlargement.

\section{Models and results}

\subsection{The influence of bilateral opinions on trade}

Our theoretical foundation for trade patterns is the standard new trade monopolistic competition-CES demand-Iceberg trade costs model first introduced by Krugman (1980) and used by many since then. Producers operating under increasing returns in each country produce differentiated varieties that they ship, with a cost, to consumers in all countries. Parameter $\phi_{i j t}$ measures the bilateral free-ness of trade between country $i$ and country $j$ in year $t$, involving both actual price-raising trade impediments and the sensitivity of consumers to an increase in price. The utility function used here contains a preference term $a_{i j t}$ representing "bilateral love" of consumers in $j$ for varieties produced in $i$. The total value of exports from $i$ to $j$ in $t$ can be written in logs as (see Redding and Venables, 2004 for instance):

$$
\ln x_{i j t}=\ln \left(n_{i t} p_{i t}^{1-\sigma}\right)+\ln \phi_{i j t}+(\sigma-1) \ln a_{i j t}+\ln \left(Y_{j t} P_{j t}^{\sigma-1}\right),
$$

with $n_{i t}$ and $p_{i t}$ the number of varieties and prices in country $i$ in $t, Y_{j t}$ and $P_{j t}$ representing the expenditure and price index of the importer country in $t$. The gravity equation can be seen as a reduced form of this theoretical trade flow prediction, where the (logged) output of country $i$ proxies for the first term, and the (logged) income of $j$ approximates the last one. Distance, common language and contiguity are usually used for $\ln \phi_{i j t}+(\sigma-1) \ln a_{i j t}$. While $n_{i t} p_{i t}^{1-\sigma}$ and $Y_{j t} P_{j t}^{\sigma-1}$ are not totally disconnected from the two GDPs of $i$ and $j$ respectively, they are crude approximations at the best, raising issues on the validity of simple gravity specifications and results.

A specification more consistent with theory involves the use of fixed effects for each importer and exporter (Hummels, 2001; Redding and Venables, 2004 use this method, notably recommended by Feenstra, 2004). The fixed effects $\mathrm{fe}_{i}$ and $\mathrm{fe}_{j}$ incorporate the size effects as in gravity, but also the other origin and destination determinants seen above, the price and the number of varieties of the exporting country and the size of demand and the price index (often referred to as a remoteness term) of the importing country:

$$
\ln x_{i j t}=\mathrm{fe}_{i}+\ln \phi_{i j t}+(\sigma-1) \ln a_{i j t}+\mathrm{fe}_{j} .
$$

We will therefore mostly use this specification together with simple gravity. Theory predicts unitary income elasticities. Following Anderson and van Wincoop (2003), we impose an unit 
coefficient on income variables in the fixed effects estimations by dividing trade volumes by the product of both partners' GDPs.

The last step is to specify free-ness of trade and bilateral preferences, $\phi_{i j t}$ and $a_{i j t}$. Trade costs that reduce $\phi_{i j t}$, are usually seen as consisting of transport costs, protection measures, and information/communication costs (Anderson and van Wincoop, 2004). Bilateral distance and common border are standard proxies for transport costs. Bilateral tariffs will be used here (in the last part of the article) as a measure of trade policy. We use two variables to proxy for information channels about profitable trade opportunities between the two countries. We first use bilateral exchanges of newspapers, news $s_{i j t}$, as a proxy for the ease of communication and quality of reciprocal information. Recent evidence on the impact of business and social networks on trade patterns has also shown that migrants can boost international commerce through different channels. One of the most important, according to empirical findings (Rauch and Trindade, 2002 for instance) is the reduction of information costs related to international trade. ${ }^{8}$

$$
\ln \phi_{i j t}=\delta_{1} \ln d_{i j}+\delta_{2} \mathrm{cb}_{i j}-(\sigma-1) \ln \operatorname{tar}_{i j t}+\delta_{3} \ln \operatorname{news}_{i j t}+\delta_{4} \ln \operatorname{asylum}_{i j} .
$$

Distance $\left(d_{i j}\right)$ between trade partners is defined as the sum of the bilateral distances between the biggest cities of countries weighted by the economic size of those cities. City population is used as weight. $\mathrm{cb}_{i j}$ is a dummy variable set to 1 for pairs of countries that share a common border. asylum $_{i j}$ is the share of asylum seekers going to a particular EU member during the period 19881993. Note that data availability for migrations is relatively poor and some values of this variable are missing.

Often, $a_{i j t}$ is specified and simplified as a home bias, mostly because no bilateral information on preferences is available to the researcher. One of our objectives in this paper is to provide a richer specification of bilateral preferences. A first set of proxy variables identifies characteristics that can make tastes of consumers more similar and hence augment the quality of the match between varieties produced in $i$ and tastes of consumers in $j$. A cultural similarity variable that has been largely used and can proxy for similar preferences is common language. Note that linguistic proximity is hard to measure in our sample: The introduction of a dummy variable is indeed not appropriate because no single pair of countries shares a common language in this sample. The use of a continuous measure of the linguistic distance between countries as in Boisso and Ferrantino (1997) or Melitz (2003) is also hard: Similarity indexes are available for an insufficient number of countries and/or only treat Indo-European languages and therefore totally ignore the three Finno-Ugric languages also present in our sample. We use a richer variable of proximity of languages spoken $\operatorname{lang}_{i j}$, that takes into account the language "families" established by linguists and uses the product of the share of populations speaking a specific language in each of the two trading partners. For each language, we first consider its family and sub-family. For example, French and English are Indo-European languages. Regarding their sub-families, French belongs to the Italic languages and English to the Germanic ones. We then define a language similarity's index which takes the value of 1 if both countries have the same language, 0.5 if the two languages belong to the

\footnotetext{
${ }^{8}$ Note that it has also been emphasized in the literature that the transmission of preferences to locals, or the reduction of opportunistic behaviour between members of the social network of migrants can facilitate trade, and could possibly enter the $a_{i j}$ term here, making it hard to discriminate between the different channels of influence.
} 
Table 2

Influence of bilateral opinions on EU imports

\begin{tabular}{|c|c|c|c|c|c|c|}
\hline \multirow{2}{*}{$\frac{\text { Dependent variable }}{\text { Model }}$} & \multicolumn{3}{|l|}{ ln imports } & \multicolumn{3}{|c|}{ ln (imports/product of GDPs) } \\
\hline & (1) & (2) & (3) & (4) & (5) & (6) \\
\hline Intercept & $\begin{array}{l}-9.62^{\mathrm{a}} \\
(1.11)\end{array}$ & $\begin{array}{l}-11.65^{\mathrm{a}} \\
(1.01)\end{array}$ & $\begin{array}{l}-12.17^{\mathrm{a}} \\
(1.07)\end{array}$ & $\begin{array}{l}-10.09^{\mathrm{a}} \\
(0.85)\end{array}$ & $\begin{array}{l}-11.58^{\mathrm{a}} \\
(1.20)\end{array}$ & $\begin{array}{l}-11.85^{\mathrm{a}} \\
(1.21)\end{array}$ \\
\hline ln GDP EU country & $0.96^{\mathrm{a}}(0.04)$ & $0.99^{\mathrm{a}}(0.04)$ & $1.01^{\mathrm{a}}(0.04)$ & & & \\
\hline ln GDP CEEC & $0.72^{\mathrm{a}}(0.04)$ & $0.70^{\mathrm{a}}(0.04)$ & $0.72^{\mathrm{a}}(0.05)$ & & & \\
\hline ln distance & $-1.43^{\mathrm{a}}(0.09)$ & $-1.40^{\mathrm{a}}(0.09)$ & $-1.43^{\mathrm{a}}(0.10)$ & $-2.18^{\mathrm{a}}(0.12)$ & $-2.11^{\mathrm{a}}(0.13)$ & $-2.09^{\mathrm{a}}(0.14)$ \\
\hline Common border & $0.37^{\mathrm{b}}(0.16)$ & $0.44^{\mathrm{a}}(0.16)$ & $0.44^{\mathrm{a}}(0.16)$ & $0.01(0.11)$ & $-0.01(0.12)$ & $-0.01(0.14)$ \\
\hline ln imports of newspapers & $0.00(0.01)$ & $0.00(0.01)$ & $0.00(0.01)$ & $-0.01(0.00)$ & $-0.01(0.00)$ & $-0.01(0.00)$ \\
\hline ln share asylum seekers & $0.15^{\mathrm{a}}(0.02)$ & $0.15^{\mathrm{a}}(0.02)$ & $0.16^{\mathrm{a}}(0.02)$ & $0.07^{\mathrm{c}}(0.04)$ & $0.06^{\mathrm{c}}(0.04)$ & $0.08^{\mathrm{b}}(0.04)$ \\
\hline Language proximity index & $-0.37(0.34)$ & $-0.26(0.34)$ & $-0.34(0.37)$ & $1.18^{\mathrm{a}}(0.36)$ & $1.05^{\mathrm{a}}(0.36)$ & $0.94^{\mathrm{a}}(0.42)$ \\
\hline ln imports of books & $0.01(0.01)$ & $0.01(0.01)$ & $0.00(0.01)$ & $0.01^{\mathrm{c}}(0.01)$ & $0.01^{\mathrm{b}}(0.01)$ & $0.01(0.01)$ \\
\hline ln bilateral opinion & & & $0.36^{\mathrm{a}}(0.11)$ & & & $0.32^{\mathrm{c}}(0.18)$ \\
\hline $\begin{array}{l}\text { In bilateral opinion } \\
\quad \text { (lagged) }\end{array}$ & & & $0.39^{\mathrm{a}}(0.11)$ & & & $0.38^{\mathrm{b}}(0.19)$ \\
\hline EU countries fixed effects & No & No & No & Yes & Yes & Yes \\
\hline CEECs fixed effects & No & No & No & Yes & Yes & Yes \\
\hline Time effects & Yes & Yes & Yes & Yes & Yes & Yes \\
\hline$N$ & 679 & 679 & 585 & 679 & 679 & 585 \\
\hline$R^{2}$ & 0.858 & 0.861 & 0.866 & 0.787 & 0.792 & 0.786 \\
\hline
\end{tabular}

Note: Newey-West standard errors in parentheses with ${ }^{\mathrm{a}, \mathrm{b}}$ and ${ }^{\mathrm{c}}$ respectively denoting significance at the $1 \%, 5 \%$ and $10 \%$ levels.

same sub-family, 0.25 if the two languages belong to two different sub-families but to the same family and 0 for two languages from two different families. Finally, the linguistic proximity between two countries is calculated by adding, for all the languages spoken by at least $3 \%$ of

Table 3

Influence of bilateral opinions on EU exports

\begin{tabular}{|c|c|c|c|c|c|c|}
\hline \multirow{2}{*}{$\frac{\text { Dependent variable }}{\text { Model }}$} & \multicolumn{3}{|l|}{$\ln$ exports } & \multicolumn{3}{|c|}{ In (exports/product of GDPs) } \\
\hline & (1) & (2) & (3) & (4) & $(5)$ & (6) \\
\hline Intercept & $\begin{array}{l}-7.13^{\mathrm{a}} \\
(0.89)\end{array}$ & $\begin{array}{l}-7.73^{\mathrm{a}} \\
(1.04)\end{array}$ & $\begin{array}{l}-8.41^{\mathrm{a}} \\
(1.02)\end{array}$ & $\begin{array}{l}-11.34^{\mathrm{a}} \\
(0.78)\end{array}$ & $\begin{array}{l}-13.35^{\mathrm{a}} \\
(1.18)\end{array}$ & $\begin{array}{l}-10.85^{\mathrm{a}} \\
(1.06)\end{array}$ \\
\hline In GDP EU country & $0.91^{\mathrm{a}}(0.04)$ & $0.92^{\mathrm{a}}(0.05)$ & $1.00^{\mathrm{a}}(0.05)$ & & & \\
\hline In GDP CEEC & $0.70^{\mathrm{a}}(0.03)$ & $0.70^{\mathrm{a}}(0.03)$ & $0.73^{\mathrm{a}}(0.04)$ & & & \\
\hline In distance & $-1.64^{\mathrm{a}}(0.09)$ & $-1.63^{\mathrm{a}}(0.09)$ & $-1.70^{\mathrm{a}}(0.09)$ & $-1.98^{\mathrm{a}}(0.10)$ & $-1.88^{\mathrm{a}}(0.11)$ & $-2.00^{\mathrm{a}}(0.11)$ \\
\hline Common border & $-0.16(0.15)$ & $-0.14(0.14)$ & $-0.11(0.13)$ & $-0.10(0.16)$ & $-0.13(0.13)$ & $-0.06(0.13)$ \\
\hline ln exports of newspapers & $0.02^{\mathrm{a}}(0.01)$ & $0.02^{\mathrm{a}}(0.01)$ & $0.01(0.01)$ & $0.01(0.00)$ & $0.01(0.00)$ & $0.00(0.00)$ \\
\hline ln share asylum seekers & $0.10^{\mathrm{a}}(0.02)$ & $0.10^{\mathrm{a}}(0.02)$ & $0.10^{\mathrm{a}}(0.02)$ & $0.02(0.03)$ & $0.02(0.03)$ & $0.02(0.04)$ \\
\hline Language proximity index & $-0.86^{\mathrm{a}}(0.32)$ & $-0.83^{\mathrm{b}}(0.33)$ & $-0.91^{\mathrm{a}}(0.35)$ & $0.45(0.32)$ & $0.29(0.32)$ & $0.36(0.36)$ \\
\hline ln exports of books & $0.02^{\mathrm{b}}(0.01)$ & $0.02^{\mathrm{b}}(0.01)$ & $0.01^{\mathrm{c}}(0.01)$ & $0.02^{\mathrm{a}}(0.01)$ & $0.02^{\mathrm{a}}(0.01)$ & $0.02^{\mathrm{a}}(0.01)$ \\
\hline ln bilateral opinion & & $0.10(0.10)$ & & & $0.42^{\mathrm{b}}(0.19)$ & \\
\hline $\begin{array}{l}\text { In bilateral opinion } \\
\text { (lagged) }\end{array}$ & & & $0.08(0.10)$ & & & $0.07(0.15)$ \\
\hline EU countries fixed effects & No & No & No & Yes & Yes & Yes \\
\hline CEECs fixed effects & No & No & No & Yes & Yes & Yes \\
\hline Time effects & Yes & Yes & Yes & Yes & Yes & Yes \\
\hline$N$ & 679 & 679 & 585 & 679 & 679 & 585 \\
\hline$R^{2}$ & 0.896 & 0.896 & 0.912 & 0.847 & 0.848 & 0.862 \\
\hline
\end{tabular}

Note: Newey-West standard errors in parentheses with ${ }^{\mathrm{a}, \mathrm{b}}$ and ${ }^{\mathrm{c}}$ respectively denoting significance at the $1 \%, 5 \%$ and $10 \%$ levels. 
the population in each country, the products of the shares of speakers in each country weighted by the language similarity index. In addition, we control for the bilateral trade in printed books, books $_{i j t}$, that should also be related to common cultural traits and therefore similar tastes of consumers.

$$
\ln a_{i j t}=\alpha_{1} \operatorname{lang}_{i j}+\alpha_{2} \ln \text { books }_{i j t} .
$$

The next step is to introduce the bilateral opinions' variables in the trade equation. The expected effect depends of course on how bilateral opinions are formed. As described in greater details in the next section, we envision several determinants of bilateral opinions on the question under study here. Opinions will reflect dimensions of both $a_{i j t}$ and $\phi_{i j t}$. For instance, a long history of violent warfare between $i$ and $j$ is likely to attach a negative image to all products coming from the "ancestral enemy", reducing $a_{i j t}$, but also to make communication and negotiation of contracts more difficult, which reduces $\phi_{i j t}$. We therefore introduce the variable opin $_{i j t}$, which measures the bilateral opinions, as described in a preceding section and have the following expectations: 1) The impact on trade should be positive, 2) The impact should be larger on imports than on exports because bilateral affinity has no reason to be strictly reciprocal, ${ }^{9}$ 3) Variables proxying for $a_{i j t}$ and $\phi_{i j t}$ should see their influence reduced when they imperfectly proxy for bilateral affinity, like for distance for instance.

Our preferred estimated equation is therefore:

$$
\begin{aligned}
\ln \left(x_{i j t} / y_{i t} y_{j t}\right)= & \mathrm{fe}_{i}+\mathrm{fe}_{j}+\delta_{1} \ln d_{i j}+\delta_{2} \mathrm{cb}_{i j}-(\sigma-1) \ln \operatorname{tar}_{i j t}+\delta_{3} \ln \operatorname{news}_{i j t} \\
& +\delta_{4} \ln \operatorname{asylum}_{i j}+(\sigma-1) \alpha_{1} \operatorname{lang}_{i j}+(\sigma-1) \alpha_{2} \ln \text { books }_{i j t}+\gamma \ln \operatorname{opin}_{i j t} \\
& +\varepsilon_{i j t},
\end{aligned}
$$

and we also present results from the "traditional", simpler but mis-specified, gravity equation. In this case, the log imports $\left(\ln x_{i j t}\right)$ are simply used as the dependent variable, fixed effects are omitted and economic sizes of trading partners are measured with their respective real GDP $\left(y_{i t}\right.$ and $y_{j t}$ ). In our sample $i=1, \ldots, n$ is one of the candidate countries, and $j=1, \ldots, N$ is an EU member (before May 1st, 2004). We also run estimations on $x_{i j t}$, the imports of candidate countries from EU members during year $t$. Year dummies are introduced in all our regressions. Results of the estimations are reported in Table 2 for imports and Table 3 for exports. The first three columns of Tables 2 and 3 report results with simple gravity estimation. Fixed effects estimation results - our preferred estimates - are reported in columns (4), (5) and (6). We controlled for the presence of heteroscedasticity in all our estimations using the Breusch-Pagan/ Cook-Weisberg test. The presence of serial correlation in our panel regressions was also investigated using the Wooldridge test. Results are available upon request, and suggest the presence of both heteroscedasticity and serial correlation. We correct both problems using Newey-West standard errors.

The overall high fit of regressions is consistent with what is found in the literature. Regarding traditional covariates, the impact of distance is stronger than the usual estimates but this comes from the fact that our sample mainly covers combinations of trading partners

\footnotetext{
${ }^{9}$ To take a well known example: Guiso et al. (2004) report that the level of bilateral trust between British and French citizens is quite below the average level of trust those two countries inspire to other countries on average. What is more unexpected is that the level of dis-trust of British citizens for French ones is more than twice the reverse level.
} 
involving ground transportation. ${ }^{10}$ Sharing a common border promotes EU imports from CEECs in the gravity equation, but the effect is not robust, and is basically nil for exports to the CEECs.

Column (2) of Table 2 introduces bilateral opinions in the simple gravity framework, and we also account for a potential simultaneity bias between the changes in trade and bilateral opinions by including the lagged value of bilateral opinion in column (3). Point estimates of the bilateral opinion variable are quite stable across specifications. Elasticities revealed by coefficients of columns (2), (3), (5) and (6) show that trade volumes rise by a value between 3.2 and $3.9 \%$ following a $10 \%$ increase in bilateral opinion. This $10 \%$ increase corresponds for instance to a 4.42 percentage points rise, when considering the average value of the opinion variable (as can be seen in the Appendix table). In our sample, a one-standard deviation increase (12.56 additional percentage points of positive opinions) from the mean value amounts to a $28 \%$ rise, which raises bilateral trade by a figure ranging between 9.3 and $11.3 \%$. The magnitude of the effect is therefore substantial in economic terms, in line with the estimates obtained by Guiso et al. (2004) with trust as an explanatory variable, and highly statistically significant. Regressions also reveal that bilateral opinions bring additional information in the explanation of trade patterns, rather than substituting for the impact of other variables proxying $\phi_{i j t}$ and $a_{i j t}$. Indeed, most of the variables keep a stable coefficient with the inclusion of bilateral opinions in the gravity specification. Note that the asylum seekers variable has a robust impact on trade flows and contributes substantially to the overall fit of the regression. With the lowest estimates of Table 2, a one-standard deviation increase from the mean of this variable raises bilateral trade by more than $11 \%$. We also test if our results are affected by our measure of migration. We use the stock of migrants from CEECs in EU countries (available from the OECD international migration statistics) as an alternative measure of migration. Results, available upon request, suggest a positive and statistically significant effect of migration on trade and the influence of bilateral opinion on trade remains unchanged. The fit of the regression is however slightly smaller. In the fixed effect specification, exchanges of newspapers never have a significant positive impact on trade. ${ }^{11}$ Finally, language proximity index, which was negative but not significant in the simple gravity estimations (columns 1 to 3 ), becomes positive and significant in columns (4) to (6). One explanation for this reversal could be that the unit coefficient imposed on income variables and the use of fixed effects affect the other estimated coefficients and especially this linguistic index.

Comparing results from Tables 2 and 3, we see that our main variable of interest loses its positive influence for exports in all except one estimations, which confirms priors if this variable mostly reflects preferences of consumers. Opinions have no reason to reflect systematically symmetrical bilateral affinity, and we do not have the information on opinions of CEEC citizens on EU countries. The difference in coefficients can therefore be interpreted as evidence that the underlying mechanism is indeed related to the affinity that consumers in the importing country have for the exporting country. Opinions are overall significant and quite large determinants of imports in our sample. Their influence is robust to the inclusion of other proxies for similar preferences and low trade costs we use here, suggesting that it contains

\footnotetext{
${ }^{10}$ Disdier and Head (in press) find that distance estimates from gravity equations are substantially larger (in absolute value) for intra-continental samples.

${ }^{11}$ Note that due to time constraints, newspapers can also be directly printed in the host country, specially when the potential readership is large there. However, we do not think that this is a significant concern in our case. Indeed, our sample includes several small countries (in particular in Central and Eastern Europe) and the market for newspapers from these countries does not seem large enough to make direct investment advantageous.
} 
additional information on the bilateral affinity of countries that translates into higher trade flows.

\subsection{Determinants of bilateral opinions}

The formation of opinions can be caused by two types of variables: the ones reflecting the economic gains/losses expected by the population to arise from the enlargement and the ones reflecting bilateral affinity. In addition, all our regressions include country-specific fixed effects (in order to account for the unobservable systematic country-specific deviations in opinions), as well as year dummy variables and a correction for heteroscedasticity and serial correlation. Naturally, when explaining opinions with economic variables, the rationale and results of the preceding section raise issues about endogeneity in general and reverse causality in particular. We set aside this problem for now, but will return to it in Section 5.

Concerning the economic determinants of opinions, we first expect that high anticipated costs of adjustment to the enlargement will translate into more negative opinions. We include three types of variables to capture this determinant: trade flows divided by the product of partners' GDPs in each direction, the difference in GDP per capita, and the difference in unemployment rates between countries. The impact of imports is of particular interest here, as a negative sign would provide support for the political economy explanation of opinion formation, while a positive one would suggest that increased trade contributes to raise bilateral affinity. Related, the current rate of unemployment might also contribute to fears of job losses in the different member countries after the enlargement. The size of the EU country is also taken into account, as it seems to be a crucial empirical determinant of the levels of opinions. This variable can be justified with the well documented fact that large countries are less open to international trade and investment. Net contributions to the EU budget might also matter, although the sign of the effect is uncertain. The current level of aid received from the European Commission under the regional policy programmes could generate negative opinions about the enlargement, as enlargement might endanger those programmes and redirect them to the CEECs. On the opposite, large net contributors might fear extended payments to be made to the new entrants. We include net contributions divided by country's GDP as a covariate as well as the amount of agriculture-related subsidies received (per farmer), which is often a key political issue in European countries. Related to this is the overall perception by citizens of the benefits their country enjoyed from membership. People might be more supportive of further integration if they view the history of the EU to date as globally positive for their country. We therefore include an additional question of the Eurobarometer survey on this topic:

"Taking everything into consideration, would you say that (our country) has on balance

benefited or not from being a member of the European Union?"

Possible answers are: "Benefited", "Not benefited" or "Don't know". We retain the percentage of positive answers. Interestingly, this perceived benefit is in fact one of the most robust determinant of positive opinions.

Opinions could also be influenced by affinity factors. One can think that bilateral affinity is primarily constructed by the history of the dyad under consideration. Ancient alliances, intense bilateral migration flows or repeated instances of political and/or cultural conflicts should impact the feeling of citizens about each candidate countries. We use several proxies to capture those historical ties likely to influence opinions. First, we use the number of military incidents $\left(\right.$ war $\left._{i j}\right)$ between the two countries within the period 1870-1989, and uncorr $i j$ which measures 
the correlation between countries' positions during votes on resolutions in the General Assembly of the United Nations. The UN votes correlation is intended to take into account shorter term political proximity. ${ }^{12}$ As another proxy for cultural and historical ties, we also use an index of religious proximity $\left(\right.$ relig $\left._{i j}\right)$, constructed in a very similar way as the language similarity index.

Bilateral affinity can also be measured by variables used for trade costs and similarity of preferences in the trade equation. A good example is our migration variable. It can capture an information channel for profitable trading opportunities, but also bilateral affinity of each EU country towards each acceding country. Indeed, during the "immediate transition period" (which we date to be between 1988 and 1993 here), we expect asylum seekers trying to change citizenship and move out of the Eastern Europe country considered to choose the EU country where their chances of positive answer and then integration, success in professional and personal life...are highest (see Hatton, 2004, for recent evidence). The share of asylum seekers going to a particular EU member at this period should therefore reflect in part the bilateral affinity of countries. We therefore include those variables for $a_{i j t}$ and $\phi_{i j t}$ as controls here.

The estimations of the influence of economic and affinity factors on bilateral opinions are presented in Table 4. The dependent variable is the percentage of respondents in each Member State that supports the enlargement to a given CEEC. These percentages belong to the $[0 ; 100]$ interval. We take into account the existence of those upper and lower bounds of the explained variable using a logistic transformation of the data (Greene, 2003).

The first four columns introduce imports and the following four exports. Columns (1) and (5) present OLS results while the other ones report fixed effects estimates. Columns (4) and (8) include lagged values of imports and exports. Imports always have a positive and significant influence in statistical terms. For exports however, the effect is not significant when lagged values are used. Besides, we note that the magnitude of the influence is higher for imports. As expected, introducing additional controls for opinions, the influence of trade variables tends to decrease. Results indicate that the difference in GDP per capita between the two countries has a negative effect on opinions. EU citizens therefore have a better opinion concerning the membership of a candidate country when this country is proximate in terms of development level. Note that proximity in income per capita seems the key factor in this type of determinant, as suggested by the insignificance of the difference in unemployment rates. Net contributions to the EU budget are positively associated with opinions about the enlargement, which means that countries receiving the most from the EU have the worst opinions about the enlargement. The fears of a reduction of EU subsidies seem to be a strong determinant of opinions across countries. The agricultural subsidies variable (not reported here) has however no significant influence, whereas the perceived benefit of the EU membership has a strong and positive influence on opinions. Regarding affinity variables, geographical proximity (short distance), combined with high levels of political proximity, of linguistic affinity and of our asylum variable is all positively associated with more positive opinions. Religious proximity has a negative sign contrary to expectations. Finally, and unlike the estimations in the previous section, the $R^{2}$ is much higher when fixed effects are included in the regression. Bilateral economic and affinity variables explain a proportion of EU citizens' opinions, but the crucial importance of fixed effects points to a large influence of fixed characteristics of each country (EU members and CEECs).

\footnotetext{
${ }^{12}$ This measure is based on the roll-call votes. This form of vote happens when one Member State requests the recording of the vote so that its stand, or the stand of another Member State, on the issue under discussion is clearly identified. This recording must be requested before the voting is conducted. Data cover the period 1946-1996. We take the mean value of annual correlation in the votes of the two trading partners between 1991 and 1996.
} 


\section{Causality through trade policy}

We have identified in the last two sections a reciprocal statistical relationship between bilateral opinions and trade. Those results do however lack insights about the causal link in

Table 4

Influence of economic and affinity factors on bilateral opinions

\begin{tabular}{|c|c|c|c|c|c|c|c|c|}
\hline \multirow{2}{*}{$\begin{array}{l}\text { Dependent variable } \\
\text { Model } \\
\end{array}$} & \multicolumn{8}{|c|}{ ln bilateral opinion } \\
\hline & (1) & (2) & (3) & (4) & (5) & (6) & (7) & $(8)$ \\
\hline Intercept & $\begin{array}{l}3.75^{\mathrm{a}} \\
(0.55)\end{array}$ & $\begin{array}{l}18.95 \\
(13.46)\end{array}$ & $\begin{array}{l}-16.92 \\
(26.71)\end{array}$ & $\begin{array}{l}9.71 \\
(34.49)\end{array}$ & $\begin{array}{l}3.31^{\mathrm{a}} \\
(0.53)\end{array}$ & $\begin{array}{l}16.15 \\
(11.88)\end{array}$ & $\begin{array}{l}-20.81 \\
(26.93)\end{array}$ & $\begin{array}{l}10.94 \\
(35.74)\end{array}$ \\
\hline ln imports/product of GDPs & $\begin{array}{l}0.10^{\mathrm{a}} \\
(0.02)\end{array}$ & $\begin{array}{l}0.13^{\mathrm{a}} \\
(0.01)\end{array}$ & $\begin{array}{l}0.06^{\mathrm{a}} \\
(0.02)\end{array}$ & & & & & \\
\hline In imports/product of GDPs (lagged) & & & & $\begin{array}{l}0.08^{\mathrm{a}} \\
(0.02)\end{array}$ & & & & \\
\hline In exports/product of GDPs & & & & & $\begin{array}{l}0.08^{\mathrm{a}} \\
(0.02)\end{array}$ & $\begin{array}{l}0.16^{\mathrm{a}} \\
(0.01)\end{array}$ & $\begin{array}{l}0.05^{\mathrm{b}} \\
(0.02)\end{array}$ & \\
\hline In exports/product of GDPs (lagged) & & & & & & & & $\begin{array}{l}0.04 \\
(0.03)\end{array}$ \\
\hline In population EU country & $\begin{array}{l}-0.14^{\mathrm{a}} \\
(0.02)\end{array}$ & $\begin{array}{l}-1.86 \\
(1.57)\end{array}$ & $\begin{array}{l}0.16 \\
(2.91)\end{array}$ & $\begin{array}{l}-3.04 \\
(3.79)\end{array}$ & $\begin{array}{l}-0.13^{\mathrm{a}} \\
(0.02)\end{array}$ & $\begin{array}{l}-1.47 \\
(1.37)\end{array}$ & $\begin{array}{l}0.73 \\
(2.94)\end{array}$ & $\begin{array}{l}-3.01 \\
(3.91)\end{array}$ \\
\hline In GDP per capital difference & & & $\begin{array}{l}-0.11^{\mathrm{c}} \\
(0.06)\end{array}$ & $\begin{array}{l}-0.15^{\mathrm{a}} \\
(0.06)\end{array}$ & & & $\begin{array}{l}-0.11^{\mathrm{c}} \\
(0.06)\end{array}$ & $\begin{array}{l}-0.15^{\mathrm{a}} \\
(0.06)\end{array}$ \\
\hline In unemployment rates difference & & & $\begin{array}{l}0.01 \\
(0.01)\end{array}$ & $\begin{array}{l}0.01 \\
(0.01)\end{array}$ & & & $\begin{array}{l}0.01 \\
(0.01)\end{array}$ & $\begin{array}{l}0.01 \\
(0.01)\end{array}$ \\
\hline Net contribution to EU budget/GDP (\%) & & & $\begin{array}{l}0.24^{\mathrm{a}} \\
(0.04)\end{array}$ & $\begin{array}{l}0.16^{\mathrm{a}} \\
(0.04)\end{array}$ & & & $\begin{array}{l}0.24^{\mathrm{a}} \\
(0.04)\end{array}$ & $\begin{array}{l}0.17^{\mathrm{a}} \\
(0.04)\end{array}$ \\
\hline ln benefited from EC membership & & & $\begin{array}{l}0.66^{\mathrm{a}} \\
(0.11)\end{array}$ & $\begin{array}{l}0.49^{\mathrm{a}} \\
(0.10)\end{array}$ & & & $\begin{array}{l}0.66^{\mathrm{a}} \\
(0.11)\end{array}$ & $\begin{array}{l}0.51^{\mathrm{a}} \\
(0.10)\end{array}$ \\
\hline No of conflict years & & & $\begin{array}{l}-0.02^{\mathrm{b}} \\
(0.01)\end{array}$ & $\begin{array}{l}-0.02^{\mathrm{a}} \\
(0.01)\end{array}$ & & & $\begin{array}{l}-0.01^{\mathrm{b}} \\
(0.01)\end{array}$ & $\begin{array}{l}-0.02^{\mathrm{a}} \\
(0.01)\end{array}$ \\
\hline ln $\mathrm{UN}$ vote correlation & & & $\begin{array}{l}3.71^{\mathrm{a}} \\
(0.75)\end{array}$ & $\begin{array}{l}4.47^{\mathrm{a}} \\
(0.69)\end{array}$ & & & $\begin{array}{l}3.48^{\mathrm{a}} \\
(0.75)\end{array}$ & $\begin{array}{l}4.03^{\mathrm{a}} \\
(0.70)\end{array}$ \\
\hline Religion proximity index & & & $\begin{array}{l}-0.30^{\mathrm{a}} \\
(0.12)\end{array}$ & $\begin{array}{l}-0.33^{\mathrm{a}} \\
(0.10)\end{array}$ & & & $\begin{array}{l}-0.35^{\mathrm{a}} \\
(0.12)\end{array}$ & $\begin{array}{l}-0.37^{\mathrm{a}} \\
(0.11)\end{array}$ \\
\hline In distance & & & $\begin{array}{l}-0.32^{\mathrm{a}} \\
(0.07)\end{array}$ & $\begin{array}{l}-0.27^{\mathrm{a}} \\
(0.06)\end{array}$ & & & $\begin{array}{l}-0.34^{\mathrm{a}} \\
(0.07)\end{array}$ & $\begin{array}{l}-0.36^{\mathrm{a}} \\
(0.07)\end{array}$ \\
\hline Common border & & & $\begin{array}{l}0.05 \\
(0.08)\end{array}$ & $\begin{array}{l}0.09 \\
(0.08)\end{array}$ & & & $\begin{array}{l}0.05 \\
(0.08)\end{array}$ & $\begin{array}{l}0.09 \\
(0.08)\end{array}$ \\
\hline In share asylum seekers & & & $\begin{array}{l}0.04^{\mathrm{c}} \\
(0.02)\end{array}$ & $\begin{array}{l}0.03 \\
(0.02)\end{array}$ & & & $\begin{array}{l}0.04^{\mathrm{c}} \\
(0.02)\end{array}$ & $\begin{array}{l}0.03^{\mathrm{c}} \\
(0.02)\end{array}$ \\
\hline ln imports of newspapers & & & $\begin{array}{l}0.00 \\
(0.00)\end{array}$ & $\begin{array}{l}0.00 \\
(0.00)\end{array}$ & & & $\begin{array}{l}0.00 \\
(0.00)\end{array}$ & $\begin{array}{l}0.00 \\
(0.00)\end{array}$ \\
\hline Language proximity index & & & $\begin{array}{l}0.54^{\mathrm{a}} \\
(0.14)\end{array}$ & $\begin{array}{l}0.54^{\mathrm{a}} \\
(0.12)\end{array}$ & & & $\begin{array}{l}0.59^{\mathrm{a}} \\
(0.13)\end{array}$ & $\begin{array}{l}0.60^{\mathrm{a}} \\
(0.13)\end{array}$ \\
\hline ln imports of books & & & $\begin{array}{l}0.00 \\
(0.00)\end{array}$ & $\begin{array}{l}-0.01^{\mathrm{a}} \\
(0.00)\end{array}$ & & & $\begin{array}{l}0.00 \\
(0.00)\end{array}$ & $\begin{array}{l}-0.01^{\mathrm{a}} \\
(0.00)\end{array}$ \\
\hline EU countries fixed effects & No & Yes & Yes & Yes & No & Yes & Yes & Yes \\
\hline CEECs fixed effects & No & Yes & Yes & Yes & No & Yes & Yes & Yes \\
\hline Time effects & Yes & Yes & Yes & Yes & Yes & Yes & Yes & Yes \\
\hline$N$ & 864 & 864 & 677 & 610 & 864 & 864 & 677 & 610 \\
\hline$R^{2}$ & 0.152 & 0.843 & 0.897 & 0.927 & 0.137 & 0.858 & 0.899 & 0.922 \\
\hline
\end{tabular}

Note: Newey-West standard errors in parentheses with ${ }^{\mathrm{a}, \mathrm{b}}$ and ${ }^{\mathrm{c}}$ respectively denoting significance at the $1 \%, 5 \%$ and $10 \%$ levels. 
this relationship and its direction. We now turn to this question. This section will notably try to use the drastic change in trade policy between the two parts of Europe during the transition process as a way to assess whether the large rise in imports following this policy change did impact the opinions in EU member countries. In order to go further than simple correlations, a strategy is to estimate the impact of an exogenous change on trade flows on bilateral opinions. Exogeneity signifying here that the change in trade volumes would themselves not be caused by a change in opinions. Trade policy is generally not the ideal candidate for an instrument. Tariffs (and trade policy in general) have been shown to be largely endogenous, because of the response of governments to demand for protection inside the country (Trefler, 1993, is one of the most famous examples of empirical support of this hypothesis of endogenous protection). In our case however, this concern has reasonable chances to be irrelevant. Indeed, the change in trade policy from EU member countries was not dictated by political economy considerations inside each country, but by the need to respond to the external pressure for membership expressed by CEECs soon after the changes in political regime. As Baldwin and Wyplosz (2003) recall, all CEECs expressed their will to enter the EU in the early nineties. In response, the EU members offered a transition period in which unilateral trade liberalization was a central element. We therefore have the uncommon experiment of a uniform (across members because of the customs union nature of the EU) and quite drastic fall in tariffs over that period, dictated by an unexpected and dramatic change in the international environment, rather than a change in the demand for protection inside each country, which might of course be affected by a change in opinions. There is an additional dimension to this change: In 1995, Austria, Sweden and Finland joined the Union. At that date, they adopted the common trade policy of the Union, which again constitutes a relatively exogenous change from their formerly independent trade policy. Finally, note that some variance in tariffs exists between CEECs, since association agreements were signed at different dates. ${ }^{13}$

What about the instrumentation of opinions? Guiso et al. (2004) propose to use history of war, commonality of religion and genetic distance as instruments for opinions (trust in their paper). There are some problems with this approach however, linked to the fact that i) the level of opinions is primarily determined by country-specific fixed effects, ii) their proposed instruments seem to have little explanatory power on the levels of bilateral trust. We prefer to use a first differences approach here that bypasses the problem of strong fixed effects determinants in levels. Note however that identifying our effects solely on the time variation of our data within pairs of countries is quite demanding, considering the small number of years we have with fully available data. Also, the cross-sectional source of the relationship between trade patterns and opinions, while badly suited to give insights about causality, is interesting per se. We will provide IV regressions on first differences using what we consider to be exogenous and robust determinants of opinions on the one hand (population, income per capita difference, unemployment rates difference, net contribution to the EU budget, and the perceived benefit from the EU). Concerning the evolution of bilateral trade, inspection of Eq. (5) reveals that variation in bilateral tariffs is the main explanation for the ratio of trade over the products of the two GDPs (exchanges of books and newspapers have very little time variation). Due to missing observations for tariffs and in order to have relatively similar time

\footnotetext{
${ }_{13}$ March 1992 for ex-Czechoslovakia, Hungary and Poland, May 1993 for Romania, December 1993 for Bulgaria, January 1995 for the three Baltic States, and January 1997 for Slovenia.
} 
periods for regressions in first differences, we consider here only the years 1992, 1997 and 2001. Results are reported in Table 5.

Column (1) in Table 5 estimates the impact of bilateral opinions on trade volumes, using the change in bilateral tariffs as the other determinant of the change in trade volumes. In column (2), the change in bilateral opinions is explained by changes in the most significant explanatory variables from the last section. Besides, this column introduces bilateral trade as an additional determinant of changes in bilateral opinions. In column (1), the tariff variable has the expected influence and coefficient close to those estimated in the literature. Results of column (2) confirm expectations for the impact of changes in the population of EU country, perceived benefits from the EU membership and aid received. Furthermore, both opinions and trade variables are not significantly different from 0 in columns (1) and (2). This result reveals that the relationships between trade and opinions from the preceding sections are in fact mostly if not entirely due to cross-sectional variation. In the last two columns, we provide estimates of IV regressions, in order to investigate the effect of more exogenous shocks to trade and

Table 5

Bilateral opinions and EU imports — first differences

\begin{tabular}{|c|c|c|c|c|}
\hline Model & (1) & (2) & (3) & (4) \\
\hline Method & OLS & OLS & IV & IV \\
\hline \multirow[t]{2}{*}{ Dependent variable } & \multirow[t]{2}{*}{$\Delta \ln (\mathrm{imp} / \mathrm{GDPs})$} & \multirow[t]{2}{*}{$\Delta \ln$ opin. } & $\Delta \ln (\mathrm{imp} / \mathrm{GDPs})$ & $\Delta \ln$ opin. \\
\hline & & & Second step & \\
\hline Intercept & $0.38^{\mathrm{a}}(0.05)$ & $-0.00(0.03)$ & $0.32^{\mathrm{a}}(0.08)$ & $-0.04(0.05)$ \\
\hline$\Delta \ln$ tariff & $-5.96^{\mathrm{c}}(3.46)$ & & $-7.15^{\mathrm{a}}(1.95)$ & \\
\hline$\Delta \ln$ EU country population & & $-3.90^{\mathrm{a}}(1.50)$ & & $-4.91^{\mathrm{b}}(2.13)$ \\
\hline$\Delta \ln$ GDP/cap difference & & $-0.09(0.10)$ & & $-0.17(0.11)$ \\
\hline$\Delta \ln$ unempl. rates difference & & $-0.00(0.01)$ & & $0.01(0.01)$ \\
\hline$\Delta$ Net cont. to EU budget/GDP & & $0.12^{\mathrm{a}}(0.02)$ & & $0.12^{\mathrm{a}}(0.03)$ \\
\hline$\Delta \ln$ perceived benefit from $\mathrm{EU}$ & & $0.72^{\mathrm{a}}(0.06)$ & & $0.59^{\mathrm{a}}(0.09)$ \\
\hline$\Delta \ln$ bilateral opinion & $0.05(0.34)$ & & $0.89^{\mathrm{b}}(0.45)$ & \\
\hline$\Delta \ln$ imports/product of GDPs & & $-0.01(0.02)$ & & $0.12(0.08)$ \\
\hline$N$ & 218 & 226 & 218 & 218 \\
\hline$R^{2}$ & 0.048 & 0.500 & 0.073 & 0.150 \\
\hline \multicolumn{5}{|l|}{ Test of overidentifying restrictions } \\
\hline$P$-value reported & & & $(0.2704)$ & \\
\hline \multirow[t]{2}{*}{ Dependent variable } & & & $\Delta \ln$ opin. & $\Delta \ln (\mathrm{imp} / \mathrm{GDPs})$ \\
\hline & & & First step & \\
\hline Intercept & & & $-0.00(0.02)$ & $0.38^{\mathrm{a}}(0.04)$ \\
\hline$\Delta \ln$ tariff & & & & $-5.89^{\mathrm{c}}(3.14)$ \\
\hline$\Delta \ln$ EU country population & & & $-3.09^{\mathrm{b}}(1.48)$ & \\
\hline$\Delta \ln$ GDP/cap difference & & & $-0.12(0.09)$ & \\
\hline$\Delta \ln$ unempl. rates difference & & & $-0.01(0.01)$ & \\
\hline$\Delta$ Net cont. to EU budget/GDP & & & $0.12^{\mathrm{a}}(0.02)$ & \\
\hline$\Delta \ln$ perceived benefit from $\mathrm{EU}$ & & & $0.67^{\mathrm{a}}(0.06)$ & \\
\hline$N$ & & & 248 & 218 \\
\hline$R^{2}$ & & & 0.436 & 0.047 \\
\hline
\end{tabular}

Note: Standard errors in parentheses with ${ }^{\mathrm{a}, \mathrm{b}}$ and ${ }^{\mathrm{c}}$ respectively denoting significance at the $1 \%, 5 \%$ and $10 \%$ levels. 
opinions on each other in the within dimension studied here. We follow Easterly and Levine (2003) and Acemoglu et al. (2001) and run two-stage least-squares regressions. For opinions, we have the following equations:

$$
\text { Second stage : } \Delta \ln \left(\operatorname{opin}_{i j t}\right)=\alpha\left[\Delta \ln \left(x_{i j t} / y_{i t} y_{j t}\right)\right]+\beta X_{i j t}+u_{i j t}
$$

First stage : $\Delta \ln \left(x_{i j t} / y_{i t} y_{j t}\right)=\gamma X_{i j t}+v_{i j t}$

where $X_{i j}$ are exogenous variables. Similar equations are estimated for bilateral trade as a dependent variable in the second stage. Instruments used for bilateral opinion and bilateral trade are reported in the first-stage regressions (bottom of columns 3 and 4 respectively). If we focus now on the results of the second-stage regressions, both coefficients of opinions and trade rise when instrumented. Results suggest that an increase in bilateral opinions for a given pair of country has a positive and significant impact on imports, when instrumented, whereas column (1) reveals that the impact of opinions is not significant in the absence of instrumentation. The influence of imports on opinions is never significant. Result of the overidentifying restrictions test in column (3) confirms the validity of our instruments. Note that in column (4) there is no overidentifying issue, as we have only one instrument. Finally, our results can be interpreted as first evidence that the impact of a rise in opinions causes imports to increase, whereas a change in imports has no measurable impact on opinions in the importing country. Caution is warranted however in interpreting those results, due to the small sample size available here, notably because of the combination of missing opinion and tariff data.

\section{Conclusion}

This paper studies the relationship between opinions in favour of the (then) upcoming Eastern enlargement expressed by citizens in current EU countries and trade flows between these two regions of Europe. We use data extracted from the Eurobarometer public opinion surveys published by the European Commission, which allows to study bilateral patterns of trade and opinions. Two central questions are investigated: First, do bilateral opinions and trade flows move together even after controlling for the known forms of proximity existing between two countries? Second, can we go further and assess in which direction does the causality go?

Our results first suggest that bilateral opinions have a statistically robust and relatively large effect on imports, even when standard and new covariates proxying for proximity between countries are controlled for. This result holds both when using standard gravity equations and fixed effects estimations. We interpret this effect as reflecting a positive impact of "bilateral affinity" on trade patterns. The effect on exports is less significant and smaller in magnitude, which supports our interpretation. We also show that it is possible to go some way towards explaining the differences in bilateral opinions among our sample. We use several determinants, based on proxies for affinity, and also on proxies suggested by trade theory and recent empirical work that might explain why some countries are more reluctant to openness in general and with some partners in particular. Finally we add country-specific effects. We show that those country specificities are important, but that the economic determinants also seem to matter and in particular bilateral imports which are positively associated with a good opinion about enlargement. Last we provide a first pass at a causality analysis, which in the case of our sample, shows a stronger impact of bilateral opinions on imports than the reverse. 


\section{Acknowledgements}

This paper is produced as part of a CEPR Research Network on 'The Economic Geography of Europe: Measurement, Testing and Policy Simulations', funded by the European Commission under the Research Training Network Programme (Contract No: HPRN-CT-2000-00069). We wish to thank Heinrich Ursprung and the two anonymous referees whose suggestions improved the paper greatly. We are grateful to Richard Baldwin, René Belderbos, Jan Fidrmuc, Sébastien Jean, Jozef Konings, André Sapir, Federico Trionfetti and seminar participants (CEPII, ERWIT 2004, HEI, Katholieke Universiteit Leuven, Second Conference of the CEPR Research Network on Trade, Industrialization and Development, University of Nottingham, Université ParisDauphine, and Université Lille 2) for fruitful discussions.

\section{Appendix A}

Table A1

Descriptive statistics on variables of interest

\begin{tabular}{|c|c|c|c|c|c|}
\hline Variable & Source & Mean & Std. dev. & Min. & Max. \\
\hline Bil. opinion ( $\%$ in favour of enlargement) & Eurobarometer & 44.26 & 12.56 & 13 & 77 \\
\hline EU imports (millions USD) & Eurostat & 543.38 & 1398.52 & 0.001 & $12,963.85$ \\
\hline EU exports (millions USD) & Eurostat & 665.32 & 1606.23 & 0.009 & $13,681.27$ \\
\hline GDP EU countries (millions USD) & World Bank & 599.95 & 615.23 & 53.65 & 2144.48 \\
\hline GDP CEECs (millions USD) & World Bank & 35.32 & 40.87 & 4.23 & 176.26 \\
\hline Distance $(\mathrm{km})$ & CEPII & 1457.44 & 663.07 & 59.62 & 3311.85 \\
\hline Common border & CIA factbook & 0.05 & 0.23 & 0 & 1 \\
\hline Population of EU countries (thousands) & World Bank & $27,908.54$ & $26,120.22$ & 3557 & 83,030 \\
\hline Unemployment rate in EU countries $(\%)$ & Eurostat & 8.54 & 3.87 & 2.50 & 23.90 \\
\hline Unemployment rate in CEECs $(\%)$ & Eurostat & 10.95 & 4.34 & 2.30 & 20.20 \\
\hline EU imports of newspapers (USD) & COMTRADE & 125.94 & 830.50 & 0 & $13,208.38$ \\
\hline EU exports of newspapers (USD) & COMTRADE & 394.11 & 2043.68 & 0 & $27,016.63$ \\
\hline EU imports of books (USD) & COMTRADE & 674.41 & 1992.97 & 0 & $21,243.94$ \\
\hline EU exports of books (USD) & COMTRADE & 1157.81 & 3118.38 & 0 & $24,556.17$ \\
\hline Asylum seekers (\%) & Eurostat & 11.84 & 22.31 & 0 & 100 \\
\hline Stocks migrants $(\%)$ & Eurostat & 11.97 & 26.83 & 0 & 98.22 \\
\hline Language proximity index & www.ethnologue.com & 0.18 & 0.10 & 0 & 0.46 \\
\hline Religion proximity index & Encyclopedia Britannica & 0.38 & 0.20 & 0.07 & 0.84 \\
\hline No. of conflict years & $\begin{array}{l}\text { Correlates Of War database } \\
\text { (http://cow2.la.psu.edu) }\end{array}$ & 2.07 & 3.31 & 0 & 12 \\
\hline $\mathrm{UN}$ vote correlation & Gartzke et al. (1999) & 84.93 & 7.31 & 66.20 & 98 \\
\hline $\begin{array}{l}\text { Net contribution to EU budget/GDP (\%) } \\
\text { Perceived benefit from }\end{array}$ & European Commission & -0.67 & 1.50 & -5.26 & 0.64 \\
\hline EU membership ( $\%$ benefited) & Eurobarometer & 54.58 & 17.01 & 21 & 90 \\
\hline Bilateral tariff (\%) & TRAINS & 1.30 & 1.08 & 0.00 & 6.13 \\
\hline
\end{tabular}

\section{References}

Acemoglu, D., Johnson, S., Robinson, J.A., 2001. The colonial origins of comparative development: an empirical investigation. American Economic Review 91, 1369-1401.

Anderson, J.E., van Wincoop, E., 2003. Gravity with gravitas: a solution to the border puzzle. American Economic Review 93, 170-192.

Anderson, J.E., van Wincoop, E., 2004. Trade costs. Journal of Economic Literature 42, 691-751.

Baldwin, R., Wyplosz, C., 2003. The Economics of European Integration. McGraw-Hill Education, Maidenhead. 
Boisso, D., Ferrantino, M., 1997. Economic distance, cultural distance, and openness in international trade: empirical puzzles. Journal of Economic Integration 12, 456-484.

Disdier, A.C., Head, K., in press. The puzzling persistence of the distance effect on bilateral trade. Review of Economics and Statistics.

Doyle, O., Fidrmuc, J., 2006. Who is in favour of enlargement? Determinants of support for EU membership in the candidate countries' referenda. European Journal of Political Economy 22, 520-543.

Easterly, W., Levine, R., 2003. Tropics, germs, and crops: how endowments influence economic development. Journal of Monetary Economics 50, 3-39.

Eichengreen, B., Irwin, D.I., 1998. The role of history in bilateral trade flows. In: Frankel, J.A. (Ed.), The Regionalization of the World Economy, National Bureau of Economic Research Project Report Series. University of Chicago Press, Chicago, pp. 33-57.

Feenstra, R., 2004. Advanced International Trade: Theory and Evidence. Princeton University Press, Princeton.

Frankel, J.A., 1997. Regional Trading Blocs. Institute for International Economics, Washington DC.

Gartzke, E., Jo, D.-J., Tucker, R., 1999. The Similarity of UN Policy Positions, 1946-96. Version 1.17. Vanderbilt University, Nashville.

Greene, W.P., 2003. Econometric Analysis — Fifth Edition. Prentice Hall, Englewood Cliffs.

Guiso, L., Sapienza, P., Zingales, L., 2004. Cultural Biases in Economic Exchange. NBER Working Paper 11005. National Bureau of Economic Research, Cambridge.

Hatton, T.J., 2004. Seeking asylum in Europe. Economic Policy 38, 5-62.

Hummels, D., 2001. Toward a Geography of Trade Costs. Manuscript. Purdue University.

Isard, W., Peck, M., 1954. Location theory and international and interregional trade theory. Quarterly Journal of Economics 68, 97-114.

Junius, K., Nitsch, V., 2001. Ethnic Ties, Search Costs and Trade: an Empirical Investigation. Manuscript. Bankgesellschaft, Berlin.

Krugman, P.R., 1980. Scale economies, product differentiation and the pattern of trade. American Economic Review 70 , 950-959.

Mayda, A.M., Rodrik, D., 2005. Why are some people (and countries) more protectionist than others? European Economic Review 49, 1393-1430.

Melitz, J., 2003. Language and Foreign Trade. CREST Working Paper 26. Centre de Recherche en Economie et Statistique, Paris. 2006 version: http://homepages.strath.ac.uk/ 00103/Language\&Trade10.pdf.

O'Rourke, K.H., Sinnott, R., 2006. The determinants of individual attitudes towards immigration. European Journal of Political Economy 22, 838-861.

Rauch, J., 2001. Business and social networks in international trade. Journal of Economic Literature 39, $1177-1203$.

Rauch, J., Trindade, V., 2002. Ethnic Chinese networks in international trade. Review of Economics and Statistics 84, $116-130$.

Redding, S., Venables, A.J., 2004. Economic geography and international inequality. Journal of International Economics $62,53-82$.

Rose, A.K., 2000. One money, one market: estimating the effect of common currencies on trade. Economic Policy 30 , $9-45$.

Tinbergen, J., 1962. Shaping the World Economy: Suggestions for an International Economic Policy. Twentieth Century Fund, New York.

Trefler, D., 1993. Trade liberalization and the theory of endogenous protection: an econometric study of U.S. import policy. Journal of Political Economy 101, 138-160.

Wagner, D., Head, K., Ries, J., 2002. Immigration and the trade of provinces. Scottish Journal of Political Economy 49, $507-525$. 